\title{
Foreign Direct Investment Inflow into Aceh province of Indonesia After Peace Agreement
}

\author{
Azhari Yahya \\ Faculty of Law, Syiah Kuala University, Banda Aceh, Indonesia
}

Foreign Direct

\begin{abstract}
Purpose - This study aims to explain current condition of investment inflow into Aceh Province of Indonesia after peace agreement between Free Aceh Movement and the Government of Indonesia was resolved. This peace agreement was achieved after both parties were involved in political conflict for three decades

Methodology - This study applies qualitative methods by using descriptive approach. Data required for this study were obtained from library research by analyzing primary and secondary resources. Primary resources were collected by analyzing current literature. Secondary resources were obtained by reviewing some previous research report, government report and other institution report which are related to this study. All collected data were analyzed by using qualitative analysis.

Findings - The results indicate that investment inflows into Aceh Province after a peace agreement have significantly increased. This condition is caused by better investment condition after Free Aceh Movement and the Government of Indonesia agree to seek a peaceful resolution through a peace agreement. It has been noted that political conflict in Aceh had occurred from 4th December 1976 until 15th August 2005. Prior to 15th August 2005 most investors were reluctant to invest in Aceh because unsecure conditions were rampant everywhere.Better investment inflow into Aceh after peace agreement is also motivated by the enactment of Law Number 11 of 2006 on the Governance of Aceh. By having this law the Government of Aceh has more power to manage and attract new investment to be invested in Aceh Province. This law provides more spaces for the Government of Aceh to provide adequate incentives and interesting facilities for certain sectors of investment to attract more inward FDI. Therefore, it is suggested that the Government of Aceh should maintain stable political condition to attract more investment inflows into Aceh in the future.
\end{abstract}

Keywords Investment, Peace Agreement, Aceh Province

All papers within this proceedings volume have been peer reviewed by the scientific committee of the Malikussaleh International Conference on Multidisciplinary Studies (MICoMS 2017).

\section{Introduction}

Foreign direct investment (FDI) is one of the important elements for economic development either for developed or developing countries. It also plays an important role in developing economic growth in both countries, namely the 'home country' (FDI provider) and 'host country' (FDI recipient). Spin-off benefits emerge in this line of thinking. From the host country's perspective, FDI is considered as a means of acquiring technologies, skills and

(C) Azhari Yahya. Published in the Emerald Reach Proceedings Series. Published by Emerald Publishing Limited. This article is published under the Creative Commons Attribution (CC BY 4.0) licence. Anyone may reproduce, distribute, translate and create derivative works of this article (for both commercial and non-commercial purposes), subject to full attribution to the original publication and authors. The full terms of this licence may be seen at http://creativecommons.org/licences/by/4.0/ legalcode
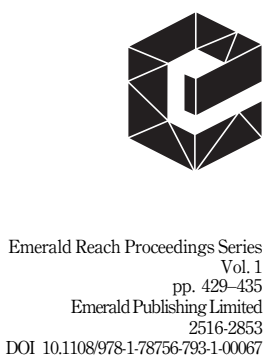
Proceedings of MICoMS 2017

\section{0}

access to international markets as well as a means of entering into a dynamic foreign trade and production system (Yahya, 2016). FDI may strengthen economic development in the host country through various means such as capital flows, employment creation, technology transfer and multiple spill over impacts.

FDI inflow has steadily increased since 1980s due to conducive investment atmosphere occurs around the world. UNCTAD (2016) reported that the aggregate FDI inflow over the last two decades have grown remarkably. Among FDI inflows around the world, majority of them flow to developed countries and the rest flow to developing countries. It is proofed that higher FDI inflow into developed countries are associated with better location determinants owned by these countries. The amount of FDI inflow into the host countries depend on the location advantages owned by these countries. Therefore, it is not surprising Indonesia as a developing country receives less inward FDI compared to other countries such as China, India and Japan because location determinants owned by these countries are much better compared to Indonesia.

Similarly, in national scope Aceh Province which is located in the far western part of Indonesia receives less inward FDI compared to other provinces in Indonesia such as North Sumatera, DKI Jakarta, West Java, East Java and South Selawesi Province. This condition is caused by better location determinants owned by these provinces compared tolocation determinants owned by Aceh (Yahya, 2007). According to Dunning FDI Theory (1993), one of location determinants that may determine FDI inflow from the home country to the host country is political stability or political conflict in the host country. Aceh as the host province for FDI inflow into Indonesia had suffered a long period of political conflict between Gerakan Aceh Merdeka (the Aceh Free Movement - hereinafter called GAM) and Indonesian Government from 1976 to 2005 (George, 2010).

During this political conflict period the amount FDI inflow into Aceh was totally low due to unsecured political condition that occurred in this province. In foreign investor's perspective unsecured political condition in the host country becomes one of the most important determinants that might be taken into account before investment decision is made. Therefore, it is quite reasonable if there were very few foreign investors invested their capital in Aceh Province during political conflict took place. Fortunately this conflict was resolved after both parties GAM and Indonesian Government agreed to sign a peace agreement in Helsinki on 15th August 2005 to end all political battle between them. According to FDI theory this peaceful condition may influence the amount of FDI inflow into Aceh Province. Therefore, this study is aimed to explain the current condition of FDI inflow into Aceh Province after a peace agreement between GAM and Indonesian Government was signed.

\section{Methods}

This study applies qualitative methods by using descriptive approach. Data required for this study were obtained from library research by analyzing primary and secondary resources. Primary resources were collected by analyzing current literature. Secondary resources were obtained by reviewing some previous research report, government report and other institution report which are related to this study. All collected data were analyzed by using qualitative analysis.

\section{Finding and discussion}

Aceh is known as a province which has enormous natural resources. With huge resource wealth makes Aceh becomes one of Indonesia's most favourable FDI destinations, especially for foreign investors. Among the natural resources to be found in the province are oil, gas, 
limestone, timber, iron, and gold. In the agricultural sector, this province also has rice, coffee, cocoa, coconut, corn, pepper, sugar cane and tobacco. The first three have been the largest commercial sectors in Aceh economy since the colonial period (Yahya, 2014). Moreover, this province also owns extensive marine resourcesconsisting of territorial water and exclusive economic zone. All these resources mean that Aceh has been able to supply enormous wealth to the central government of Indonesia through various FDI projects spread around the province. Even though this province is rich in resources, it remains one of the poorest parts of Indonesia. Around 85\% of the total Acehnese population work in agriculture, while the rest look to various sectors such as trading, industry and paid labour for their main livelihoods (Yahya, 2014).

Aceh was given special power through Law Number 11 of 2006 to manage its own FDI regime. This law was the response of Indonesian central government to a long historical conflict with the separatist movement known as GAM. As a result of this change, the government of Aceh is able to run the government affairs in all sectors except for monetary, fiscal policies, foreign affairs, judiciary and religious affairs. These powers are kept by the central government ensure that Aceh remains as an integral part of the Indonesian state. Despite these residual powers held by Jakarta, the government of Aceh now has more power to create its own policies in any sector including FDI. As a result, provincial FDI policies began to reflect local conditions. In other words, the Acehnese government has been given full authority to create local policies to attract more inward FDI to enhance provincial development and administer the development of these policies. Now Aceh has power to decide which projects to be approved when issuing investment licences either to domestic or foreign interests, and any conditions attached to investment in the region.

The law more generally reflects a highly significant change in the distribution of power between Aceh and Jakarta. Amongst other things, the government of Aceh could now create incentives to attract foreign investors using various instruments including lower tax rates, tax holidays and joint-venture agreements between the foreign company and local government of Aceh. Few years after the introduction of Law Number 11 of 2006, the government of Aceh enacted a local government regulation (using the Arabic nomenclature Qanun) Number 4 of 2013. This Qanun requires district governments in Aceh to treat all investors, whether domestic or foreign, in the same manner.

Referred to the Law Number 25 of 2007 on Investment, the most significant additions created by the government to facilitate investment are in the following forms: (a) tax reductions, (b) free import fees, (c) tax free status to all imported goods which are related to investment in Aceh as well as freedom from export taxes to all finished goods produced in Aceh, (d) infrastructure facilities to support investment as well as immigration services for foreign investors and their staff, and (e) various fiscal facilities. All these measures demonstrate the degree to which the government of Aceh is placing its hopes on FDI to enhance provincial development. The result has shown that the government of Aceh has been highly committed to facilitate FDI activities. The increase in incoming FDI suggests that the provincial government has been successful in this regard.

Aceh has been open to FDI since 1967, when the government of Indonesia passed the Law Number 1 of 1967 on Foreign Direct Investment and now this law has been replaced by the Law Number 25 of 2007 on Investment. Since then many foreign investors have come to explore the natural resources in Aceh. After quick exploration, some foreign companies began to invest their capital in this province especially in oil, gas, timber and agricultural sectors. Table 1 shows the total FDI inflow into Aceh Province since 1968.

Table 1 shows that FDI inflows into Aceh have fluctuated dramatically between 1968 and 2011. Significant inflows were followed by years when there was no foreign investment

Foreign Direct Investment Inflow



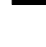




\section{8}

1969-1979

23,161,000

1980

1981

$\begin{array}{ll}432 & 1982-1985 \\ & 1986\end{array}$

N/A
$200,088,000$

1987-1988

$18,386,480$

1989

1990

1991-1992

1993

1994

1995

1996

1997

1998

1999

2000

Table 1. 2015

at all. One of the main factors behind these fluctuations was the tragic political conflict between GAM and Indonesian government. The GAM insurgency was the defining characteristic of Aceh from 1967 to 2005. The first flow of FDI into Aceh stimulated the insurgency and included investment by the US oil company Exxon Mobil, which explored for oil and gas in the northern part of Aceh. Problem arose because of unequal profit-sharing arrangement between the region and the central government. At that time, under the Soeharto regime, the profit-sharing system from such natural resources exploitation specified that all profits should go to Jakarta first. In a second step, the central government would then redistribute these profits to all provinces equally based on population amount (Jaya, 2007).

As a result, Aceh which has a very low population, only received a very small portion from the 'big oil cake' when compared with the portion received by the provinces in Java Island, a more densely populated region. This condition created a sense of locality-based injustice amongst the Acehnese people. As they saw it, resources from the region were being sold for the benefit of people elsewhere in Indonesia. This condition shows that how FDI 
project caused protests to arise in Aceh. Event took a tragic turn when the protests turned into an ethnic separatist movement.

Subsequently, in 1976 a number of Acehnese, under the leadership of Muhammad HasanTiro, established the GAM separatist movement. After a long negotiation process this conflict ended through a peace agreement process known as the Helsinki Accord, which was signed between the Indonesian government and the GAM in Helsinki on 15 August 2005 (Barron and Burke 2008, Aspinall, 2009; Ziegenhain 2010; Kingsbury 2010; George 2010). The conflict had been a long and bloody one (perhaps up to 15,000 people were killed), and has left many traces in contemporary Aceh. The civil strife had a significant negative impact on inward flow of FDI into Aceh. The data above showed that after 1968, the year in which FDI first came to Aceh, was no more foreign investment in that province until 1979. From 1979, foreign investors remained uncertain about the security of their investments, with the result that years of large inflows oscillated with years of small or no inflow.

When FDI inflow increased, they were frequently in response to government incentives. For example, in 1980-1981 some FDI returned to Aceh after the governor of Aceh guaranteed the security of foreign companies. Despite the sporadic violence caused by the political conflict, FDI inflows into Aceh started to rise in 1989 as a response to better economic growth in Aceh as a whole. This condition also confirms the study conducted by Ajide (2017) showing that higher economic growth in the host country may attract more inward FDI from overseas. As Table 1 shows, FDI then again collapsed in the early 1990s but then intermittently recovered, only to collapse again right up to 2011. In that period, the global financial crisis severely hit the economy of Aceh, resulting in less inward FDI investment in 1998 and 1999. After that FDI inflow steadily increases until 2017.

In short, it is undeniable that FDI represents many key arguments in favour of capital mobility. Seen from a macroeconomic point of view, it would be hard to deny that FDI projects have brought some significant benefits for economic development such as increasing national revenues, increasing per capita Gross Domestic Product and better economic growth in the recipient countries. However, this kind of development is highly contested by other actors, especially those touched by the local effects of FDI projects. In Aceh Province, the right to exploit natural resources had a role in the long political conflict between the Indonesian Government and GAM by which this conflict had caused enormous lost. Upon the thawing of that conflict, the central government of Indonesia gave special autonomy to the government of Aceh to deal directly with foreign investors.

These effects frequently lead to tensions that cause social conflict between the foreign company (representative of FDI) and local communities who are living in the area where the company operates. This tension pits local interests against national ones: extractive industries such as oil, gas and mining promise great financial benefits that register positively on the national balance sheet. Yet these industries frequently cause trouble such as environmental degradation, land disputes and social conflict. Even though these activities might increase government revenues at the national level, at the local level this extraction can result in massive social resistance from local communities.

Moreover, in some cases, this social hostility could cause massive grass-roots political movements that might contest the supremacy of central government in the host country. A celebrated example was the unequal distribution of oil revenues which became a source of conflict between the government of Sudan and the Sudanese People's Liberation Army/ Movement (SPLA/M). In this case, the main cause underpinning the conflict was unequal profit sharing received by local people living in the province where the oil was extracted (Patey, 2006). The disagreement stirred up regional and centre tension. A similar situation also emerged in Aceh.

\section{Foreign Direct Investment Inflow}

433

$\longrightarrow$


Proceedings of MICoMS 2017
There are also many other countries that have experienced similar conflict situations as a result of the operation of foreign companies within their borders such as Columbia, Angola, the Democratic Republic of Congo, the Caucasus, Myanmar, Bolivia, and Mexico. In these countries, foreign companies have been identified as factors behind many social conflicts and even civil wars. In these cases, FDI may exacerbate an existing tense relationship between national governments and local people in regions where natural resources such as oil, gas, timber, diamonds and precious metals are extracted (Patey, 2006).

In short, it can be highlighted that countries which are dependent on oil and mineral wealth face a much higher danger of social conflict and even civil war than the countries which are poor in resources. In other words, countries which are heavily dependent on the export of oil and minerals extracted by foreign companies face a high risk of social conflict or civil war. This civil war was caused by the unequal sharing of profits from natural resource extraction between central government and local communities. These conditions also frequently happen in Aceh after foreign investors come to invest in this province.

\section{Conclusion}

It can be concluded that FDI has played an important role in strengthening economic development in Aceh Province as the host province of FDI destination. Aceh has received FDI inflow since 1968 and continues to receive the same FDI scheme until now. The number of FDI inflow into Aceh has fluctuated all the times due to unsecured political condition that occurs all the times in this province. During political conflict period the total amount of FDI inflow into Aceh Province was very low. In this period of time GAM wanted Aceh to be independence from Indonesia so that Aceh can manage its own natural resources freely. However, Indonesian government totally disagree with this idea so that political conflict between both parties cannot be avoided. The impact of this conflict was that very few foreign investors invested their capital into this province so that economic development during this period was very slow. Fortunately FDI has been recovered after the peaceagreement has been achieved by both parties. Since then FDI starts to flow from various countries to Aceh Province with various sectors of investment. As a result economic development has grown significantly and more new jobs have been created. This fact shows that political stability as one of FDI determinants play significant role in attracting inward FDI into Aceh Province. It means that FDI inflow into Aceh returns to normal after a peace agreement has been achieved. By then investment inflow into Aceh Province after a peace agreement has significantly increased. This condition is caused by better political stability that occurs after a peace agreement has been achieved. Finally, it is suggested that the Government of Aceh should maintain stable political condition to attract more investment inflows into Aceh in the future.

\section{References}

Ajide, FM (2017), "Firm-specific and institutional determinants of corporate investments in Nigeria", Future Business Journal, Vol. 3, pp. 107-118.

Aspinall, E 2009, Islam and Nation: Separatist Rebellion in Aceh, Indonesia, Stanford University Press, Stanford USA.

Barron, P and Burke, A (2008), Supporting peace in Aceh: Development agencies and international involvement, East-West Center, Washington DC

Dunning, J (1993), Multinational enterprises and the global economy, Addison-Wesley, Wokingham, England. 
George, K M 2010, "Picturing Aceh: Violence, religion and painter's tales" in Arndt Graf, Susanne Schroter \& Edwin Wieringa (eds), Aceh: History, Politics and Culture, ISEAS Publishing, Singapore, pp. 243-264.

Jaya, W K 2007, “An institutional approach to fiscal decentralization in Indonesia: An assessment of the

Foreign Direct Investment Inflow regional autonomy reforms between 1999 and 2004", PhD Thesis, Monash University.

Kingsbury, D (2010), "The Aceh peace process", in Arndt Graf, Susanne Schroter \& Edwin Wieringa (eds), Aceh: History, Politics and Culture, ISEAS Publishing, Singapore, pp 135-156.

Patey, L 2006, "A complexity: the strategic behaviour of multinational oil corporations and the new wars in Sudan", Research report of Danish Institute for International Studies, Copenhagen.

UNCTAD (2016), "World Investment Report”, United Nations Conference on Trade and Development, New York.

Yahya, A (2007), "The location determinants and provincial distribution of Foreign direct investment in Indonesia”, Research Report, School of Economics and Governance, Australian National Univesity.

Yahya, A (2014), "Foreign Direct Investment and locality: A case study of French Multinational in Aceh, Indonesia”, PhD Thesis, Monash University, Australia.

Yahya, A (2016), "Location determinants of foreign direct investment in Indonesia", Proceeding of International Conference on Economics and Business, Gajahmada University, Yogyakarta Indonesia Vol. 4 (1), pp. 322-345.

Ziegenhain, P (2010), "The Aceh conflict during the new order and the following democraticzation process" in in Arndt Graf, Susanne Schroter, Edwin Wieringa (eds), Aceh: History, Politics and Culture, ISEAS Publishing, Singapore, pp.120-134.

\section{Corresponding author}

Azhari can be contacted at azhari.yahya@unsyiah.ac.id 